\title{
5. Sacred Genealogies of Development: Christianity and the Indian Modern
}

\author{
Kalpana Ram \\ Macquarie University
}

\section{Introduction}

The term "development" is by now indelibly associated in much critical social theory with "discourse," in the sense that Michel Foucault made his own. ${ }^{1}$ Writing in the wake of an earlier decade's work on colonialism as discourse, Arturo Escobar celebrates the possibilities of extending Foucault's method to development. ${ }^{2}$ But-like any method-discourse analysis brings with it characteristic preoccupations and orientations that foreclose certain possibilities while opening up others. Once a methodological stance is adopted, certain consequences are set in motion. Escobar wishes "to show in detail how development works." ${ }^{\prime 3}$ But his enterprise now becomes identical with setting out "to show how a corpus of rational techniques-planning, methods of measurement and assessment, professional knowledges, institutional practices and the like - organises both forms of knowledge and types of power, relating one to the other, in the construction and treatment of specific problems."

In India, despite the fact that Foucault's analysis of discourses was meant to shift the argument away from a Marxist preoccupation with state power, it is the earlier tradition which continued to shape the analytics of postcolonial scholarship. The state, both colonial and postcolonial, continued to dominate analyses - the difference is that now, state "discourses" became the locus of the exercise of power. "Development" became identified by influential scholars of Indian nationalism such as Partha Chatterjee with the "developmental state," the developmental state with developmental state discourses, and, in a further

\footnotetext{
1 In this chapter I take Foucault's method of discourse analysis as a widely known and utilised aspect of the social sciences. But see for example, Michel Foucault, Discipline and Punish: The Birth of the Prison, trans. Alan Sheridan, New York: Random House, 1977.

2 Arturo Escobar, Encountering Development. The Making and Unmaking of the Third World, Princeton: Princeton University Press, 1995.

3 Escobar, Encountering Development, p. 18.

4 Ibid.

5 Partha Chatterjee, The Nation and its Fragments. Colonial and Postcolonial Histories, Delhi: Oxford University Press, 1994.
} 
narrowing of scope, developmental discourses became rationalising discourses. The characteristic discourse of development became that of the planners. The rhythm of development is now identified with the homogeneous measured time of the Five Year Plan.

My scepticism is not directed at a broader historical argument, the argument that the Indian state was quintessentially "developmental" when it emerged as the independent nation. Unlike the account provided by Escobar-who begins his narrative with the Truman Doctrine of the post-war period- - "developmentalism" in India had its antecedents in an anti-colonial critique. This critique took the form of an economic indictment of colonialism. The immiseration of India's artisanal industries came to stand for a state whose interests did not coincide with the welfare of its people. ${ }^{6}$ But if the postcolonial state was developmental, it does not follow that development can be understood entirely in terms of the state. Nor can we assume that development can be understood entirely as a rationalising episteme, or even exclusively as an episteme for that matter. For the young people I write about in this paper, and especially the young women, the experience of development was deeply affective, capable of transforming their experience of temporality and bodily experience. I speak principally of young women in rural Tamil Nadu whom I have encountered in the course of field work over the years, who have been fully engaged in propagating developmental projects of health, democratisation and employment. Although their experience certainly entails engagement with new forms of knowledge, it exceeds what can be captured in discourse analysis. The temporality of development, for them, was neither regulated, nor planned. Instead of the homogeneous empty time of planners, or even the linear time of progress, theirs was a charged experience of past and present, one which served to break temporality into two. Even to a sympathetic outsider such as myself, there was no discernible "event" that could be held accountable for such a rupture: all I could identify was the ongoing process of being trained and seeking to educate others around them. But in the experience of the young women, their present and future was divided, not simply from their own past, but from the past that continued to be embodied in their mothers' ways of doing things.

In order to integrate such experiences into the account we give of Indian modernity, we need to direct our attention to genealogies other than the rationalising and systematising operations of expert discourses, and towards institutions other than the state. The urgency of additional perspectives is felt with particular force when undertaking ethnographic or any empirical research which considers the experience of actors-or, as Michel de Certeau

6 Satish Deshpande, “Imagined Economies," Journal of Arts and Ideas 25(26) (1993): 5-35; Chatterjee, The Nation and its Fragments; Manu Goswami, Producing India. From Colonial Economy to National Space, Chicago and London: University of Chicago Press, 2004. 
would put it - the perspective of the users of discourses ${ }^{7}$ rather than those discourses viewed, as Foucault does, systemically, in a more abstract fashion. Anthropologists have certainly been quick to point out that "to think of the discourse of development is far too limiting ... within development there is and has always been a multiplicity of voices, 'a multiplicity of knowledges,' even if some are more powerful than others." ${ }^{\prime 8}$ But the language of this re-formulation perpetuates the assumption of an exclusively epistemic relationship to the world. All that has been altered is that we now have many "knowledges," instead of one. I have recently argued at length for the indispensability of thoroughgoing alternatives to the dominant "mentalist" philosophical traditions which continue to shape many aspects of the social sciences. These alternatives should integrate affect and emotions with a much fuller version of bodily experience than is commonly made available. ${ }^{9}$ In this paper I bring that argument to bear on the method of genealogy. We must include among the genealogies of the modern those that are not simply rationalising and systematising, but are charged with the affective force of the sacred. We may find that neglected genealogies are capable of transforming even rationalising endeavours. The work on the visual imaginary of Indian nationalism is pertinent here, for it suggests that the rationalising project of mapping the colony, a fundamental example of Foucault's thesis on power and knowledge, corresponds only to the perspective of one side, that of a colonial state intent on turning unknown territory into knowable manageable "space". But the devotional effects of nationalism transformed this geometric measurable space. As a result of affective involvement, the tapering map of India was clothed in a sari, the shape of the map became the curving female form of Mother India, and the entire image was given life by the sacred energy and beauty of the luminous Hindu goddess. For nationalists, such a map "interpellates" its viewers - it "calls out" and exhorts her (male) devotees to liberate her from foreign conquest. ${ }^{10}$

But we need to look at more than Hinduism for our sacral genealogies of the Indian modern. I suggest in this paper that the terms in which young women speak of their involvement, and their understanding of the changes that flow from their involvement, take up a model provided by Christianity. It is not Christianity in general that is relevant as a genealogy for these purposes. Genealogies do not bear down on the present as a totality, nor as a unitary essence - unlike essentialist understandings of how "tradition" works. Instead, relevant parts are picked out

7 Michel de Certeau, The Practice of Everyday Life, Berkeley: University of California Press, 1984.

8 R.D. Grillo, "Discourses of development: the view from anthropology," in Discourses of Development. Anthropological Perspectives, ed. R.D. Grillo and R.L. Stirrat, Oxford and New York: Berg, 1997, pp. 1-34, p. 22.

9 Kalpana Ram, Fertile Disorder: Spirit Possession and its Provocation of the Modern, Honolulu: University of Hawai'i Press, 2013.

10 Sumathi Ramaswamy, “Visualising India's geo-body: globes, maps, bodyscapes," in Beyond Appearances? Visual Practices and Ideologies in Modern India, ed. Sumathi Ramaswamy, New Delhi and London: Sage Publications, 2003, pp. 151-90; Goswami, Producing India. 
by different kinds of projects. For instance, it is not the confessional aspects of Christianity emphasised by Foucault that are apposite for the experiences I seek to describe here. ${ }^{11}$ Rather, it is the charged experience of conversion as described by phenomenologists of religion as varied as Martin Heidegger and William James. ${ }^{12}$ Both use the trope of an affectively laden, decisive turning to describe conversion. For James, writing in his Varieties of Religious Experience, ${ }^{13}$ it is the turn from a divided self to a unified one that separates the past from the present of conversion. For Heidegger, the turning or kehre captures the experience of early Christians, whose "turn" towards a new beginning transforms their experience of time itself. Of particular importance for this essay is the manner in which Heidegger uses his own move away from a scholastic version of theology to the affective Christianity of Martin Luther, as well as that of the early Christians, as a means of "rejecting the calendrical time (chronos) of worldly reckoning for the "moment" (kairos) of insight and revelation."14

Certain obstacles lie in the way of a fuller acknowledgement of the place of Christianity in Indian modernity - on the part above all of the dominant category of Indian intellectuals, who come equipped with the tacit background and assumptions of middle class Hinduism. Missionary Christianity's involvement with the colonial project constitutes a particularly salient impediment. I well recall my own grandfather coming out with sharply honed defences of Hinduism, seemingly out of nowhere. In fact they were sharp rejoinders to the slurs he and his generation had heard or read from missionaries, colonial administrators, scholars and Western doctors - as well as from Islamic critiques - directed at "idol worshippers." The representatives of colonial rule may have left India, but the necessity of "talking back" to colonial interlocutors continued to shape the rhetoric of a whole generation of Indians. A lively literary representation of a robust response by a Hindu to a missionary occurs in the novel Chikaveera Rajendra, written by one of Karnataka's leading writers, Masti Venakatesa Iyengar. ${ }^{15}$ It is set in the last days of a small Kannada kingdom of Kodagu, before its takeover by the British East India Company. Fr. Megling's request for a debate to prove the superiority of Christianity is part of the wider British-led manoeuvrings to unseat the king, but also to destroy the autonomy of the kingdom.

11 Michel Foucault, The History of Sexuality. Volume 1: An Introduction, Harmondsworth: Penguin Books, 1978.

12 Martin Heidegger, Being and Time, trans. John Macquarie and Edward Robinson, Oxford: Blackwell, 1962. William James, Varieties of Religious Experience, New York: Penguin Books, [1902] 1985.

13 James, Varieties of Religious Experience, cited by both Eliza Kent, Converting Women. Gender and Protestant Christianity in Colonial South India, New York: Oxford University Press, 2004, pp. 5-6; and Gauri Viswanathan, Outside the Fold. Conversion, Modernity and Belief, Delhi: Oxford University Press, 1998, p. 84. 14 Charles Bambach, Heidegger, Dilthey, and the Crisis of Historicism, Ithaca and London: Cornell University Press 1995, p. 212.

15 Masti Venakatesa Iyengar, Chikaveera Rajendra, New Delhi: Penguin Books, 1992. 
Megling opened the discussion:

"We maintain that our religion which was established by Jesus Christ is superior to yours. Do you have anything to say?"

The Hindu guru answers:

"We aren't schooled in the art of discussing our faith. You are welcome to claim that your religion is superior. We believe that our religion is equally great."

Fr. Megling responds:

"Instead of worshipping the only One, who is the Lord of the Universe, you worship many lesser Gods. That is not the way to redemption. We want you to have faith in our god and be redeemed.... One more thing. You make idols of your gods and worship the idols. You claim that God manifests himself in the form of man, even a pig and fish. You have a monkey for his servant and you claim that it crossed an ocean. You mislead the people with all these fantastic stories. All this is very wrong."

After being harangued by Fr. Megling in this fashion for some time, Bhagavati stands up. She is a striking figure of a woman, a shamanic priestess of the goddess. She is granted permission to respond to the padre:

"You have found much in our religion to criticise. May I ask you to say something about your own faith?... You say God the Father, don't you? Not the Mother?"

"You are right. It's God, our Father."

"Your concept of God includes the Son also."

"Right, our concept of God includes the Father, the Son, and the Holy Ghost."

"He has no wife?"

"No."

"How did he beget his son then?"

“There's no limit to his power."

"Why shouldn't God who can beget a son without having a wife not take the form of a monkey and cross the ocean?"

"I don't see what one has got to do with the other." 
"If you attribute miracles to the enormous power that resides in God, why do you find fault when we explain our miracles in terms of the same source of power?"

"Your words display an incomplete grasp of our faith, madam. I'm sure you are just repeating the words you have heard elsewhere."

"You are right. I'm sure you haven't learnt things about our religion in any other way. You are also repeating what you heard other people say." ${ }^{16}$

Bhagavati's acute responses eventually have the crowds cheering - and it is impossible for the anti-colonial intellectual, with sensibilities further honed by two decades of postcolonial critique, not to join them in the general jubilation. But the politics of this response are no longer, if they ever were, simply anticolonial. The resentment sown by this mode of high-handed dismissal and characterisation of Hinduism has also been garnered and mobilised by rightwing Hindu nationalism specifically in order to target Christian conversion. For Hindu nationalists, Hinduism exists as a kind of originary identity for all Indians, an identity from which conquering religions have wrested them either by force, as with Islam, or by offering material incentives, as in the case of Christian missionaries. In this discourse, the connection between development and Christianity is indeed recognised, but only in order to denigrate conversion as an instrumentally motivated undertaking - both on the part of missionaries who offer material blandishments, and on the part of the Dalits and the Adivasi or "tribal" groupings, who made up the bulk of converts in the nineteenth and twentieth centuries. Discrediting conversion has paved the way for "reclaiming" converts for the Hindu fold. Equally, it has paved the way for a number of states in India to pass "anti-conversion" legislation ostensibly aimed at the use of "force, fraud and allurement."17 The legislation has legitimised violence against missionaries and Christian communities. ${ }^{18}$ In Tamil Nadu, where sections of the Dalit movement have meanwhile appropriated the Bible as locus of a Dalit Christianity, the legislation has legitimised anti-Dalit violence. ${ }^{19}$

The argument of this paper takes on its wider urgency against this political background. I seek to show that far from being an alien intrusive presence in India, sequestered in "backward" minority communities, Christianity has entered into some of the most recognisable streams of Indian modernity.

16 Ibid., pp. 144-48.

17 Goldie Osuri, Religious Freedom in India. Sovereignty and (Anti) Conversion, London and New York: Routledge, 2012, pp. 2-3.

18 Rowena Robinson, "Christian communities of India: a social and historical overview," in Religions and Development India Working Papers Series 1(1), New Delhi: Indian Institute of Dalit Studies, 2010, pp. 1-41.

19 David Mosse, The Saint in the Banyan Tree. Christianity and Caste Society in India, Berkeley: University of California Press, 2012, p. 198. 
These include not only developmental agendas, but emancipatory intellectual and political traditions that call for activist engagement, such as feminism and socialism which have enjoyed a strong presence in Indian political life. ${ }^{20}$

In what follows, I propose to highlight two levels at which Christianity can be said to have provided a genealogy for development. The first is that of the church as an institution which has been a primary agent of governmentality, in all its forms, on the west coast of Tamil Nadu. The second level is that of conversion. Taken together, both these levels allow us to consider genealogies other than the state for both colonial and postcolonial India. The genealogical enterprise I propose is, in principle, somewhat different to writing ethnographies of communities who are themselves Christian. But doing ethnographic field work in a Christian community can also provide, as it has in my case, the signal provocation for re-thinking many of the tacit and foundational assumptions which arise when an intellectual belongs to a majority community, whether in terms of gender, class/caste or religion. So in this paper the two enterprises, the genealogical and the ethnographic, come together. While I have also undertaken comparative field work among Dalits in Chengalpattu District of Tamil Nadu, the ethnography that inspires this paper is taken from my work with the Catholic fisher-people on the west coast of Tamil Nadu, who form a spatially continuous coastal settlement from Kerala to the Cape at the southern tip of India.

\section{The church as medium of governmentality: Coastal villages}

My field work began in the 1980s, before the great watershed sometimes described in abbreviated form as the "LPG era" - the era of liberalisation, privatisation and globalisation. ${ }^{21}$ The temporal rift generated in Indian political and social life by this vast change is yet to be fully comprehended in terms of its effects across different classes and regions in India. A postcolonial state that was committed to sponsoring industrialisation, protecting the economy against foreign capital, regulating the market and upholding goals for social re-distribution, remained recognisable in its contours even in Indira Gandhi's period. The "LPG era" brought with it a reversal of every one of these premises. As one commentator put it: "With a massive thrust towards privatisation, the state has been in retreat since then. Each of the incentives of the 1970s has been

\footnotetext{
20 Kalpana Ram, "Temporality and sorge in the ethical fashioning of the feminist self," in Women Making Time: Contemporary Feminist Critique and Cultural Analysis, ed. Elizabeth McMahon and Brigitta Olumbas, Crawley: University of Western Australia Press, 2006, pp. 191-220.

21 Mary John and Satish Deshpande, "Theorising the present: problems and possibilities," in Economic and Political Weekly 43(46) (2008): 83-86, p. 84.
} 
reversed. Taxation levels of the rich are down to their lowest ever, food subsidies have been cut, corporates have been allowed entry into crop procurement and public investment in agriculture is at a historical low." ${ }^{22}$

The transformation is thus generally understood as a retreat of the state from its former role. In a further contribution that evoked wide commentary and debate, Chatterjee has argued that it is only now, possibly for the first time, that rural peasant communities are imbricated in the meshes of governmentality: "Governmental agencies distributing education, health services, food, roadways, water, electricity, agricultural technology, emergency relief and dozens of other welfare services have penetrated deep into the interior of everyday peasant life.... Institutions of the state, or at least governmental agencies (whether state or non-state) have become internal aspects of the peasant community." 23

To comprehend the experience of rural coastal Christian communities requires us to abandon these ways of periodising governmentality, as I propose to show by drawing on field material prior to liberalisation. In the 1980s, state "fisheries development" was at best a distant presence, at worst, a source of dissension and disruption insofar as it meant a policy of mechanising fishing boats. Mechanisation benefitted an elite in the nearby coastal township of Colachel, but brought with it a disruption of tacit agreements over rights to fishing territories among different coastal villages. Increasingly, fisher-people in other parts of Tamil Nadu were organising to put pressure on the state to institute and police a five-mile zone from which trawling would be banned. But in Kanyakumari, the responses of kattumaram fishermen (origin of the English word catamaran), more typically took the form of direct tactics such as slashing trawling nets and damaging propellers. The state was therefore more typically encountered in its punitive and repressive aspects, in encounters with police. Predictably, the tense relationship between coastal villagers and the state was conflated by outsiders with the absence of law itself. Coastal villages were and are often seen as wild zones, prone to sudden inexplicable bouts of violence, drunkenness, social and cultural backwardness and poverty. This perception persists in the representations of school teachers in village primary schools and of social workers who participated in developmental initiatives. ${ }^{24}$ Even in my most recent trip to south India in 2012, I found that the fisher-people in the metropolis of Chennai are plagued by similar perceptions of them as lawless communities. This perception paves the way for their displacement from Marina Beach by high rise development.

22 Mihir Shah, "Structures of power in Indian Society: a response," Economic and Political Weekly, 43(46) (2008): 78-83, p. 80 .

23 Chatterjee, The Nation and its Fragments, p. 54.

24 Ram, Fertile Disorder: p. 22. 
But the relative absence of the state does not mean that governmentality was not present. Let me take first the welfare aspects of governmentality. Although the welfare state was non-existent in the villages, reform-oriented clergy were proliferating schemes for improvement. A simple preliminary listing of the schemes run by clerics in Kanyakumari District gives some idea of the broad terrain covered by such initiatives:

1. Fr. Pierre Gillet, a Belgian Catholic, was working for the Kottar Social Service Society in Kanyakumari, to develop "appropriate technology" for "artisanal" fishermen. Fr. Gillet developed motorization of the kattumaram, as well as developing a fibre-glass model of the traditional kattumaram. ${ }^{25}$

2. The Belgian sisters who worked for the Kottar Social Service Society (KSSS) had started a health network with particular focus on coastal communities. They were training young women from villages as health workers who could instigate new modern practices among women, in terms of pregnancy, birth, child nutrition and child health.

3. The weaving of fishing nets had traditionally been performed by younger women in fishing villages. Sister Delphine in the convent at the Cape of Kanyakumari had organised young women into centres where they could weave fishing nets collectively. When mechanisation of netweaving entered the district in 1979, this was recognised as a threat to female employment and Sister Delphine organised and led the protests against the machines. In the long run the protest was unable to stop the machines and the number of women involved in net-weaving had fallen dramatically by 2000 .

4. The model of sovereign power exercised by the church was actively challenged by the more radical clergy, who favoured instead a direct popular participation model of self-government. Echoing some earlier anarchist ideals of direct democracy, and drawing also on Latin American models of liberation theology, a charismatic Tamil priest called Fr. Edwin was particularly influential in Kanyakumari in initiating a scheme for localising democratic participation. He described the scheme many years later at a presentation to the World Social Forum held in Mumbai in 2004. His vision was to make the neighbourhood the basic unit of democratic self-management. ${ }^{26}$ The neighbourhood samuham or council was in turn to set up a "cabinet," equipped with "chief ministers" and "ministers" in charge of portfolios of health, hygiene, environment, income generation, children and adolescent guidance. While delegates could be chosen for village level units, all the way up to the district level, the essence of the democratic process was training

25 Pierre Gillet, Small is Difficult: The Pangs and Successes of Small Boat Technology Transfer in South India, Nagercoil: Centre for Appropriate Technology, 1985.

26 M.J. Edwin, Address to Workshop "Spiritualities and identities in the dialogue of civilizations," World Social Forum, Mumbai, 2004, online: http://www.lebret-irfed.org/IMG/pdf/Edwin.pdf, accessed 14 April 2013. 
people to engage in dialogue. In coastal Kanyakumari, the devolution of authority was essentially from the church to the neighbourhood, not from the state to the neighborhood.

5. Social workers employed by Catholic NGOs, teachers and clerics were engaged in trying out new schemes for combatting alcoholism among the men. Certain new drugs were becoming available which were said to make the drinker averse to drink. In nearby Colachel, where fishing households also raised pigs, clerics and social workers collaborated in trying to separate the residential space of households from that of pigs.

6. Some of the educated village girls were reading and teaching from reformist tracts published by clerics. ${ }^{27}$ These tracts aimed at combatting superstition and ignorance in relation to sexuality. Puberty rituals were excoriated as the opposite of a true knowledge of the physiological changes in the body; the treatment of illness as spirit possession was opposed to the proper treatment of mental illness by a psychiatrist. Other reformist tracts were urging a companionate model of marriage based on mutual love and understanding.

Far from outsiders' perception of coastal villages as lacking in governance, these projects cover an extraordinarily wide range of reforms from labour issues to the proper governance of the village, the home and the space of the domestic. Yet, to understand the authority and positioning of the nuns and priests in coastal areas, we have to bring in older aspects of governmentality such as the exercise of sovereign power. In coastal areas, such power has been invested in the church rather than the state. But first, a few words about the cultural history of Christianity in fishing communities. Fishing communities, as I argued in my early monograph, ${ }^{28}$ are dwellers in a distinctive tinai - the ancient Tamil poetic term for an ecological-cum-cultural landscape. They depend on the sea rather than the land for their livelihood, and as such have enjoyed a certain distance from the agrarian caste order, a relationship mediated by trade rather than by direct labour and servitude as with Dalit communities. ${ }^{29}$ The gender relations of the coastal communities are notably more egalitarian and complementary than in agrarian caste society - women manage and sustain the ongoing rhythms of social life on land during the daily and seasonal absences of men on fishing trips, ${ }^{30}$ while older women who work as fish traders are strikingly visible figures in their

27 See Kalpana Ram, "Rationalism, cultural nationalism and the reform of body politics: minority intellectuals of the Tamil Catholic community," in Social Reform, Sexuality and the State, ed. Patricia Uberoi, New Delhi: Sage Publications, 1996, pp. 291-318; Ram, "Maternity and the story of enlightenment in the colonies: Tamil coastal women, South India," in Maternities and Modernities. Colonial and Postcolonial Experiences in Asia and the Pacific, ed. Kalpana Ram and Margaret Jolly, Cambridge: Cambridge University Press, 1998, pp. 114-43.

28 Kalpana Ram, Mukkuvar Women. Gender, Hegemony and Capitalist Transformation in a South Indian Fishing Community, London and New Jersey: Zed Press, 1991, p. 6.

29 Ibid., p. 22.

30 Ram, Mukkuvar Women; see also Cecilia Busby, The Performance of Gender. An Anthropology of Everyday Life in a South Indian Fishing Village, London and New Brunswick: Athlone, 2000. 
indigo cotton saris, mobile presences travelling to market towns in the district. This general distinctiveness has been augmented by Christianity. Visually, no coastal village, practically from Kerala down to the Cape of Kanyakumari would be complete without the pastel-coloured whites, greens, creams and pinks of the large church and the shrine to the village's patron saint standing out against the glare of the sea, sun and sand. The history of the church in these coastal villages goes back to the sixteenth century, with the conversion of fishing communities in response to the efforts of Jesuit Portuguese missionaries and the arrival of St. Francis Xavier. Indeed, the wholesale conversion of fishing communities, with some 45,000 baptised Roman Catholics in the coastal regions of Kerala and Tamil Nadu by the end of the sixteenth century, ${ }^{31}$ may be said to have set the precedence for the later "mass" conversions of agrarian lower castes that occurred in the nineteenth and twentieth centuries. The effect of this long history of involvement with Christianity has been to fuse Catholicism inextricably with the style of life and occupational identity of a sea-oriented people, ${ }^{32}$ known in this part of Tamil Nadu as Mukkuvars.

The quasi-sovereign role of the church in coastal villages is buttressed by a bureaucracy that extends beyond any individual village. This role is reflected in the transitory character of the parish priest who is transferable across the diocese, but it also extends into transnational connections that allow the flow of clergy between India and Western countries. Fishing families dream of having a gifted son who will become an educated parish priest in the Church. The old matriarch in the household I lived with in the village flew the black flag of mourning to declare her son symbolically dead when he thwarted her clerical ambitions for him by choosing to marry for love. The parish priest provided the immediate source of governance in village politics, presiding over everything from the adjudication of disputes, appointing villagers to positions of authority such as the village kannakapillai or accountant, and ritually presiding over the baptism of babies and fishing vessels alike, to punishing misdemeanours by making wrong-doers parade publicly holding a cross in hand, collecting a tithe as a percentage of the daily fishing catch. Indeed such authority has been in tension not only with sexual liaisons, but with the texture of popular Catholicism in matters such as healing and spirit possession. ${ }^{33}$

When this state-like character of the church is noticed by outsiders, it does little to alleviate the disfavour that surrounds coastal fishing villages. Instead, it conjures up the spectre of a state within a state. ${ }^{34}$ At its worst, this reputation has fuelled hostile political mobilisation. In other parts of India, and certainly

\footnotetext{
31 Cecilia Busby, "Renewable icons," in The Anthropology of Christianity, ed. Fenella Cannell, Durham and London: Duke University Press, 2006, pp. 77-98, p. 79.

32 Ram, Mukkuvar Women, p. 31.

33 Ram, Mukkuvar Women; Ram, Fertile Disorder.

34 Ram, "Rationalism, cultural nationalism and the reform of body politics," p. 298.
} 
in southern India, Hindu nationalism made inroads only from the 1990s. But the coastal belt, densely settled with exclusively Christian communities, has long suffered from its representation as the domain of an alien Christian power. Hindu nationalist organisations such as the Rashtriya Swayamsevak Sangh (RSS) began their propaganda in the late 1970s, agitating for a large memorial to the nationalist figure Vivekananda at the Cape. The building of the memorial was itself disruptive for fisher-people, and was in turn used to fuel tensions between Hindus and Christians. In 1982, when I arrived on the scene, violent attacks on the Christian fisher-people by Hindus were very fresh in people's experience. Yet the hostile imagery of a theocratic state enclosed within a nation state was echoed even by the official Commission of Inquiry, supposedly conducting a neutral investigation into the violence:

By way of explaining the firings on groups of fishers, police officials and district administrators spoke of the defiance of the fishing community, which only recognised the rule of religion. In statements echoing RSS rhetoric about a monolithic minority impervious to national law and order, they depicted the coast as a theocracy within a secular nationstate and attributed fisher "intransigence" to the consolidation of Christian clerical power on the coast and the increase in money power through fisheries development. ${ }^{35}$

If the reigning image of Christianity in coastal Kanyakumari has been that of a theocratic feudal and alien institution keeping a modern progressive secular Indian state at bay, the reality is quite the opposite. Active modernisation was propagated by the nuns and priests, rather than by the state. Schemes proposed by clerics were comfortably able to involve secular professionals such as school teachers, health workers, social workers. The issues that people brought to the village councils and to priests were similarly secular in character, and reflected many of the characteristics of coastal communities. A journal kept by the newly instituted Village General Body or Samuham in Fr. Edwin's parish noted the issues that were being brought for adjudication. I list them below:

1. Peace talks are requested after clash between two families in the village, which has also involved kin in other villages.

2. A fish vendor is harassed by the family of her daughter's lover - his family holds her responsible for not properly controlling her daughter. Her husband is away on seasonal migration, and the boyfriend's family is threatening to dishonour her other daughters in retaliation. She seeks safety from the council.

35 Ajantha Subramaniam, "Mukkuvar modernity: development as a cultural identity," in Regional Modernities. The Cultural Politics of Development in India, ed. S. Sivaramakrishnan and Arun Agarwal, New Delhi: Oxford University Press, 2003, pp. 262-85, p. 277. 
3. The sale of the family house is disputed by a returning fisherman back from seasonal migration - he has chased out the new occupants, and they seek compensation.

4. A woman complains about having given another family a loan of Rs.20,000 to buy a boat. The family has disappeared after re-paying only a fraction of the loan. She wants the party traced and the money recouped.

5. A fish vendor complains that her neighbour takes advantage of the fact that both she and her husband (a fisherman) are away during the day and the daughters are alone. She is concerned that it is her daughters whose reputation will be damaged.

6. A woman complains that she is harassed for not giving the full dowry.

7. A woman has been deserted by her husband. She initially left home during pregnancy after a fight, and went back to her mother's. The husband then refused responsibility for the child, and during one of his seasonal trips to Kerala, married a woman there. She tried to buy back their house from her exhusband's family, but they now deny receiving money and are allowing the husband to re-occupy it. She would like to at least have her money returned.

8. The mechanised boats from this village are disturbing the kattumarams in a neighbouring fishing village, and a dispute is simmering.

9. The samuham has been asked to write a letter on behalf of a girl who was pressured into an abortion by her boyfriend, who said he did not want a shotgun marriage but would marry her. He is now rescinding his promise of marriage.

10. The samuham is asked to organise water supply and the extension of water pipes to this section of the village. ${ }^{36}$

The village council is here being asked to adjudicate on disputes that carry with them all the flavour and texture of social life in a coastal village: domestic disputes over escalating rates of dowry, ${ }^{37}$ the incapacity of working parents to protect the safety and reputation of their daughters, and wives who find themselves made vulnerable to second marriages and liaisons by the seasonal pattern of male absences. Even the disputes over money reflect the dense network of credit that binds and divides fishing households.$^{38}$ Not only do a striking number of these issues concern women, but it is older women who bring these to the council, reflecting their prominence as traders, money lenders and mainstays of households during the absence of men.

36 This journal, maintained by the newly instituted village general body, was viewed on site at the coastal village where Fr. Edwin was the parish priest.

37 Ram, Mukkuvar Women.

38 Ibid. 


\section{Development as conversion: The sacred effects of some secular experiences}

If the initiatives I have described above cannot be classified as purely religious, neither can they be described as "secular" in any clear cut manner. The reformist clergy themselves felt quite capable of moving readily between secular and Christian discourses. In his 2003 address, speaking to an international audience, Fr. Edwin described his early successes in the district of Kanyakumari. By the time he left the district, he had succeeded in setting up 7,000 neighbourhood parliaments. To this audience, he was quite readily able to re-present, and to re-label in secular terms, what he had originally called "Basic Christian Communities." The term he now used was a "Neighbourhood Networking of Communities." Yet the role of prayer and invocations of divinity never disappeared from his political project. His early experiments began with prayers. In his address to the international audience, he reaffirmed his conviction that all are "children of one divine reality." 39

But it was among young women of the coastal villages that the blending of the secular and the sacred was most dramatic, even if less immediately obvious as such. I have written elsewhere of these young women. ${ }^{40}$ Many of them were working for Christian non-government organisations, or were trained as teachers and social workers. Many were unemployed. Many were unmarried or in the early years of marriage. But all were imbued with deep aspirations for a better life than that of their mothers. Their use of the language of development shows a characteristic emphasis on a radical expansion of horizons. Although they utilised the developmental language of a contrast between a generalised "backward" past and a present which must be animated by munnērrram or "progress", what they emphasised in equal proportion was a transformed experience of the self. The old self, fearful and constrained, became open to the world and emboldened to move about in it. Their discourse borrowed the antinomy between ignorance and enlightenment that their teachers conveyed, but gave it an activist orientation. Two young people, a brother and sister called Marie Terese and Fernandes, told me of Fr. Edwin's message to them: "He told us how for 400 years the coastal people had lived in ignorance. Our

39 Edwin, "Spiritualities and identities in the dialogue of civilizations."

40 Ram, “Uneven modernities and ambivalent sexualities: women's constructions of puberty in coastal Kanyakumari, Tamilnadu," in A Question of Silence? The Sexual Economies of Modern India, ed. Mary E. John and Janaki Nair, New Delhi: Kali for Women, 1998, pp. 269-304; Ram, “A new consciousness must come': affectivity and movement in Tamil Dalit women's activist engagement with cosmopolitan modernity," in Anthropology and the New Cosmopolitanism, ed. Pnina Werbner, Oxford and New York: Berg, 2008, pp. 135-55; Ram, “'I now have arivu [knowledge] which dispels fears': instabilities in what it means to 'know' and the effects of Tamil political party and civil society intellectuals on rural women's discourses in South Asia," Special issue, Democracy, Civil Society and Governance: Contemporary Challenges in India 32(3) (2009): 485-500. 
level of education has always been lower than the rest of the district - there is a huge amount of ignorance." ${ }^{41}$ This discourse sounds extremely hierarchical, setting apart the educated from the ignorant. And indeed, it did have, as one of its effects, a strikingly new version of the hierarchy between the old and the young. Older women became the embodiment of ignorance for matters such as their maternal practices. According to Jeanette, a health worker:

Amma [mother] would keep a katti [iron knife] in the ashes of the stove to keep the spirits from hearing the cry of the baby. When my baby was small, I was told not to go in front of women who had lost babies before birth - if I did chance on one, I was told I should give them my baby to hold for a little while. There are many müta nampikkai [backward, foolish, irrational beliefs] around. They bathe fully in the water-only then do they feel that the heat of the body is reduced. We advise them not to do that. They do not eat eggs and milk in case the baby gets too big and they have a difficult birth. ${ }^{42}$

While a certain pride was often taken by the young women who were educating "the mothers," the reversal of authority relations between older and younger generations was even more salient. Older women who had traditionally been the mainstays of the coastal community - hardy, active and mobile presences and not simply "mothers" - now emerged in the discourse of young people as good pupils, progressing after attending a number of "mothers' meetings." This is Maria Terese: "Then we young people began working on our parents, and slowly some things began to change ... we have spoken in samuhams about the relation between hygiene and disease... The mothers are also now confident enough to go themselves, to send petitions, go to the Municipal office, go the Collector's office." 43

Jeanette, the young health worker, told me of the women in her village:

But $75 \%$ change their minds after we answer their questions. There is great awareness about immunisation and hygiene, and treatment for diarrhoea. Where before no liquid was given, now they give the sugar and salt solution. For vysoori [small pox], they seek hospital treatment. At the last mothers' meetings the women suggested writing to the Block Development Officer over the lack of electricity and water pumps in the village; finally they went there themselves and broke their water pots outside the office. ${ }^{44}$

41 Kalpana Ram in discussion with Marie Terese and Fernandes, coastal village of Kanyakumari District, 1983.

42 Ram in interview with Jeanette, a health worker with NGO, in coastal village of Kanyakumari District, Dec. 1991.

43 Ram in discussion with Maria Terese, coastal Kanyakumari 1983.

44 Ram in interview with Jeanette, December 1991. 
Ambrose, an unmarried woman of 27 , had dedicated her life to health initiatives, and was working as a midwife for a Catholic non-government organisation. Here she speaks of the women who came to her for advice:

I tell them-namma bodykku namma bodporuppu-we alone are responsible for our bodies... Great problems beset our women. Men who come home with alcohol and blue movies on the brain, who won't take "no" for an answer, beat them. On the other hand, women get blamed for having children. I see many effects of our efforts. Those exposed to our talks stand out in any crowd, they talk differently to others. There is great muny effec [progress]. ${ }^{45}$

But development brought with it more than just a restructuring of knowledge. It also brought a new affective and bodily sense of emancipation. It was not so much the older "pupils," but their young teachers who expressed this sense of emancipation. As the young women left their homes and villages to take part in collective training at missions, and found employment in non-government organisations, the conditions of their daily existence were transformed. As Maria Terese put it to me:

A great change is visible in the freedom allowed to us girls. I tell you, our own house was one where my aunty has been beaten for scaling fish seated on the verandah even though she was behind a thatch screen. Before the samuham I could not go out of the house freely let alone out of the village. Today, I can move everywhere and even stay away a week visiting another village to spread these ideas. ${ }^{46}$

Young men also spoke of a new expanded horizon: "Before, if someone came to our village, we would shy away, feel suspicious, afraid in case what we said got us into some kind of trouble. But today, we feel 'they are also human beings such as ourselves,' and we talk openly to people such as yourself." ${ }^{47}$

It was among the young women - rather than the young men - that this narrative of emancipatory self-transformation was most striking. The reasons for this had to do with the far greater constraints placed on the motility and mobility of young women. In the aftermath of the kinds of public comments made by religious and political leaders after the gang rape in Delhi in December 2012, it is clearer than ever that the attempt to make women responsible for preventing sexual violence against them, through increased self-surveillance, is not simply a phenomenon of "rural backwardness" but reflects a shared set of norms about gender relations all over India. The restrictions entailed disciplining each

45 Ram in discussion with midwife Ambrose, Kanyakumari, January 1992.

46 Ram in discussion with Maria Terese, Kanyakumari, 1983.

47 Ram in discussion with Fernandes, Kanyakumari, 1983. 
aspect of everyday bodily behaviour: speech, comportment, dress, visibility to others, all forms of social intercourse with others, and motility in general. ${ }^{48}$ The enlarged perspective on the world experienced by these young women was, accordingly, not simply a mental or an epistemic shift. Although their explicit project was the dissemination of new knowledge, the sense of liberation was in keeping with the bodily nature of the restrictions to which they were subjected in the first place. Liberation took the form of a greater embodied movement in the world. It resulted in the boldness to raise questions, but it is experienced in bodily terms as "one's mouth being loosened":

Appa (father) would impose restrictions on me for coming home late from KSS meetings, but I would explain what it was about. I was told to look out - my sister-in-law's ghost might "come on me" [possess her] she burnt herself alive. But my mouth has been loosened since the KSS and I ask them right back: what ill has befallen me? I have done all sorts of things I was never supposed to have done. Has anything happened to $\mathrm{me}$ ? $^{49}$

It is apposite at this point to compare the experiences of these women with that of recently converted Dalits in Tamil Nadu. Here David Mosse describes the narratives of change enunciated by recent converts to Christianity:

In the 1980s, Alapuram Paraiyar men and women would often characterise their aspirations to me in terms of the notion of nākarikam-that is, civility, politeness, urbanity ... in contradistinction to a servile past that was identified as acinkam [degrading, disgusting or shameful].... Apart from signifying a difference in caste relationships, the acinkam / $n \bar{a} k a r i \bar{k} a m$ dichotomy was part of a Paraiyar narrative of change and of their own changeability. It was within this discourse that people spoke of their conversion to Protestant Christianity.... Perhaps its greater historical proximity made conversion more readily a topic in interview ... but perhaps it was also that Paraiyar discourse on identity was itself more culturally disjunctive, for which Christianity provided an idiom of expression ... these Protestant Paraiyars repudiated rather than glorified their past. ${ }^{50}$

Like my respondents, these recently converted Protestant Dalits also contrast the oppression of the past with their hopes for a more civilised, less subservient future. Both groups stress the changeability of their past oppression. But the Dalit focus is entirely on caste degradation, whereas the women in coastal Kanyakumari area spoke primarily of a past in which they were sequestered,

48 Ram, Fertile Disorder.

49 Ram in interview with Jeanette, Kanyakumari District, December 1991.

50 Mosse, The Saint in the Banyan Tree, pp. 182-83. 
hemmed in, restricted and policed, as women. Their new present, which abounded with images of enlightenment, was intimately tied to greater mobility as women. Among my respondents, the language of female liberation cut across caste. Although most of them were from coastal fishing communities, women from higher castes singled out their sense of their restrictions as women in even more acute terms. Ambrose, the midwife, was from the Maravar caste, a landholding family, but now in a penurious state. She was particularly caustic about the gender norms in her community: "In my family traditionally women did not come out in the daytime. Even now I cannot visit my relatives in day. In my clan and community there are families where the men are alcoholic, womanising, squandering their family wealth - but still the women could not go out to support the family or earn money." ${ }^{51}$

The restrictions placed on women are of an extraordinarily intimate nature, not simply because they have to police every aspect of their own everyday behaviour, but because those who ask them to do so are their own families, who love them and whom they love. We may contrast this to caste oppression which can be externalised. The generation of fear of reprisals may be felt by both Dalits and women, but among women, it is mediated by love. The fear is not just of making oneself vulnerable by departing from the gender-specific codes of conduct. It is a fear of the censure that one's actions would bring; the loss of reputation of one's family. For the majority of young girls I interviewed, such norms seemed unavoidable. Agency lay for them in ensuring that they policed their own movements rather than waiting for their families and community to do so. ${ }^{52}$ Participating in development programmes offered young women a rare opportunity for an expanded version of agency: they could move around with greater freedom while retaining respectability.

\section{Colonial genealogies of development: Missions versus the colonial state}

In this last section I want to reflect more closely on the sense in which colonial Christianity forms a potent and ongoing tradition for secular projects. Insofar as development entails deliberate and wide-ranging interventions in order to re-shape the lives of those considered "backward,"53 a closer genealogy is provided, not by the state, but by missions. Despite missionary suspicions of the material economic and political considerations at work in the "mass" conversion of south India, missions themselves enacted a hybridisation of spiritual and

51 Ram in interview with Ambrose, Kanyakumari District, January 1992.

52 Ram, “Uneven modernities and ambivalent sexualities," pp. 269-304.

53 See also Ram, Fertile Disorder. 
secular colonial projects in bringing both enlightenment and civilisation to the natives. The genealogy I seek to demonstrate is more than just a distant model. Many of the specific endeavours and modes of intervention I have referred to for coastal villages have their antecedents in missionary efforts to alter modes of daily life. The London Missionary Society in south India sought to bring respectable standards of clothing to men and women, notably directing women to cover their breasts. The conflicts which ensued have been termed the Breast Cloth Controversy of Travancore, an episode favoured by historians for its capacity to illuminate the complex intersection of dissonant meanings at work. I draw in this segment particularly on the recent work of Eliza Kent on gender and Protestant missions in south India to bring together my ethnography with the colonial history. ${ }^{54}$ For missions, the project was to bring civilised modesty to women from the lower caste of Nadars. The garment they wished women to wear was, in fact, not a breast cloth, but a sewn jacket..$^{55}$ It was the Nadar men and women who wanted to wear the upper cloth that was reserved for upper castes. For them, it was a sign of upward mobility and a militant declaration that the women were no longer sexually available to upper castes. The violent response of upper castes to both the Nadars and the missions only confirms the local politics at stake.

Colonial commentaries on "native life" for the region accord a condescending approval to Mukkuvar women for covering their breasts: "The inelegant but decent dress of the Roman Catholic fisherwomen appears to be the result of a curious compromise between barbarous laws and female modesty-they cover the bosom straight across with a cloth which runs under each arm."

By the time of my field work, it did not need priests to instigate sartorial change in coastal villages. Middle-class norms on the proper way to wear a sari, evolved in interaction with Victorian norms, had been generalised. Young women wore tightly sewn blouses and petticoats, although they still diverged from my middle-class tastes in preferring nylon saris to cotton handloom saris. ${ }^{57}$ Their mothers, especially the older women, continued to resist blouses and petticoats, looking altogether cooler than the rest of us in the heat.

Other direct continuities with the past are to be found in the efforts of reformist parish priests to stop coastal people from raising pigs in close proximity to their living space. Kent's research shows that when, in the late nineteenth century, missionaries finally reconciled themselves to the low caste of their converts,

\footnotetext{
54 Kent, Converting Women.

55 Ibid., p. 207.

56 Mateer Native Life in Travancore, London: W. H Allen, 1883, cited in Kent, Converting Women, p. 207.

57 On the particular relationship between handloom weaving and the formation of an Indian middle-class taste, there is an extensive literature, but see Emma Tarlo, Clothing Matters. Dress and Identity in India, London: Hurst and Company, 1996. Tarlo also discusses the turn to synthetics.
} 
in contrast to far more prestigious upper-caste conversions they had worked for, they discovered new challenges to their notions of domesticity. Uppercaste households had been found wanting because they were too confining, unhygienic as well as amoral in their sequestering of women in purdah and zenanas. Lower-caste households posed quite the opposite problems of unsuitability. They were just too porous, lacking proper boundaries between inside and outside the home..$^{58}$ Reports frequently mention the disruption to missionary teachers in such homes - apart from crying babies, the presence of animals is a frequent candidate for censure. As part of the effort to bring techniques of "home management" into Indian homes, model homes were built "according to Western standards of privacy, hygiene and order, with separate rooms for different functions and human inhabitants separated from nonhuman inhabitants." ${ }^{59}$

I have referred in this paper, and extensively elsewhere, ${ }^{60}$ to the contemporary reformist manuals authored by male clerics, propounding the virtues of companionate marriage, extolling the virtues of maternal love as a model of unselfishness, and generally opposing superstitious older ways of ritually marking the life cycle. These texts are written in a very characteristic style: rich in literary allusions taken from Tamil classics, peppered with aphorisms and popular proverbs. All these thematic and stylistic devices were pioneered by Christian missions. One example in particular stands out for my purposes from Kent's account - a tract written by Anna Satthianadhan, a Tamil woman who belonged to the fourth generation of Indian converts. ${ }^{61}$ Satthianadhan's home, unlike the "chaos" of lower-caste homes, is described with approval by European visitors as having "tokens of refinement" such as chairs, sofas and tables, and offering "quiet comfort and a place of welcome for friends." ${ }^{62}$ In 1862, Satthianadhan wrote Nalla Tāy, possibly the first mothering manual written in south India. ${ }^{63}$ But what is striking for present purposes is that Nalla Tāy set the definitive precedent for blending Tamil traditions of both literary and the popular, with new messages of childrearing. Some of the more arresting proverbs employed by Satthianadhan have found their way into the reformist manuals of today.

The contrast between these extensive interventions into people's daily lives and the colonial state's attitude to "native life" could not be more striking. To the chagrin of missionaries, District collectors actively participated in temple

58 Kent, Converting Women, p. 158.

59 Ibid., p. 160.

60 Kalpana Ram, "Rationalism, cultural nationalism and the reform of body politics"; Ram, "Maternity and

the story of enlightenment in the colonies"; Ram, Fertile Disorder.

61 Kent, Converting Women, pp. 145-49.

62 Ibid., p. 185.

63 Annal Satthianadhan, Nalla Tāy (The Good Mother), 1862, Madras: Christian Literature Society for India, 1921, cited in Kent, Converting Women, pp. 145-47. 
festivals like any Hindu raja, making sure they collected temple taxes at the same time. ${ }^{64}$ When the state did intervene in gender relations, over such matters as sati or widow immolation, it did so not in the name of European norms, but in the name of upholding the true scriptural tradition of the Hindus, located by orientalist scholars in Sanskrit classical texts. ${ }^{65}$ In other words, the intervention of the state took the form described by Edward Said-that of restoring to natives their own tradition based on a study of "a lost, past classical Oriental grandeur." ${ }^{\prime 66}$ Missions were therefore at odds with the state, and until 1813, the East India Company actively forbade missions from preaching in the regions where it did business "out of fear that they would destabilize the region." ${ }^{16}$ Gauri Viswanathan's work on conversion reveals further compromises on the part of the state. ${ }^{68}$ When asked by converts or their families to adjudicate on the severed or strained ties between the Christian convert and their community, British court rulings tended to support the latter-ostensibly to protect the inheritance rights of the convert, but driven more by political apprehension. They feared introducing instabilities into what were taken to be the fixed and stable religious identities of Hindu and Muslim. ${ }^{69}$

By 1835 the orientation of the colonial state had shifted..$^{70}$ The "Anglicists," led by Thomas Macaulay, initiated an era of state-sponsored Western education in order to create Indians who would be "Indian in blood and colour, but English in taste, in opinions, in morals, and in intellect" - a remark of Macaulay's that is widely quoted in India. ${ }^{71}$ But this state project was limited to the Indian elite. The zeal to take Christ and clinic to zones of backwardness - "to the far-flung corners of the Indian Empire - the forbidden space of zenanas in town and city as well as the 'wild' frontiers of the Afghan border" remained a hallmark of missions, while these remained spaces that "the colonial state in the first half of the nineteenth century had itself feared to tread."72

The genealogy I am arguing for was not only inherited by specific projects that I found still underway in rural Tamil Nadu, but also enabled the ease with

\footnotetext{
64 Kent, Converting Women, p. 39.

65 Lata Mani, Contentious Traditions: The Debate on Sati in Colonial India, Berkeley: University of California Press, 1998; Viswanathan, Outside the Fold, p. 78.

66 Edward Said, Orientalism: Western Conceptions of the Orient, London: Penguin, 1978, p. 79.

67 Kent, Converting Women, p. 23.

68 Viswanathan, Outside the Fold.

69 Ibid., p. 78.

70 Sanjay Seth, Subject Lessons. The Western Education of Colonial India, Durham and London: Duke University Press, 2007; Viswanathan, Outside the Fold.

71 T.B. Macaulay, "Minute by the Honorable T.B Macaulay, 2nd February 1835," in Bureau of Education, Selections from Educational Records, Part I (1781-1839), ed. H. Sharp, Calcutta: Superintendent, Government Printing, 1920, reprint, Delhi: National Archives of India, 1965, pp. 107-17.

72 Sandhya Shetty, "(Dis)Locating gender space and medical discourse in colonial India," in Eroticism and Containment. Notes from the Flood Plain, ed. Carol Siegel and Ann Kibbey, New York and London: New York University Press, 1994, pp. 188-232, p. 193.
} 
which clerics could substitute a religious terminology for a secular one, and the ready mingling of clerical and other kinds of secular personnel in development programmes. The ground work for such ease and movement was laid in the nineteenth century.

It remains only to remark on one last but important genealogical legacy. In a stimulating paper on colonial missions in south India, Jane Haggis argued that the conservatism of the gender model preached by Christian missionaries was contradicted by the activism required of missionary wives and the single educated women who came to India during the late nineteenth century as "lady missionaries." 73 There were implications for Indian women as well. The "mission of sisterhood" sought to reach upper-caste Hindu women as prestigious converts, but relied on the efforts and activism of lower-caste women newly trained as Bible women. Not only were these women increasingly trained in a professionalising manner, but to carry out their duties required of them a "range of public activities calling for considerable stamina and self-confidence." 74

The young women in today's development programs can be seen as the direct descendants of Bible women. Both groups belong to the same region of south India, known in the colonial period as Travancore. But the more fundamental continuity is in the pattern of female agency which is unleashed in the process of bringing enlightenment to others. In both cases, such agency exceeds anything envisaged by the discourse on which they rely. The young women I write about come from communities that were Catholic in the sixteenth century. They are neither recent converts, nor professionals conveying a religious discourse. Yet the religious experience of conversion is pertinent, I would suggest, in illuminating their experience. But a further question arises at this point. Which model of conversion are we to utilise? Those who, like Kent, have examined colonial mission experiences in detail, draw a sharp distinction between the psychological "interiorist" model of conversion as an "intense, one-on-one encounter between the self and God," ${ }^{\prime \prime 5}$ and the situation that pertains in the colonies. Enmeshed in the unequal power relations between themselves and their converts, she argues, missionaries could not bring themselves to credit their converts with the "capacity for interiority that is a necessary condition for an inner, private experience of conversion."76 Faced instead with mass conversions that followed the lines of group identity (caste, family, village), missionaries fell back on requiring converts to attest to their transformation "through far-reaching changes in their daily lives and everyday practices."77

\footnotetext{
73 Jane Haggis, “'Good wives and mothers' or 'dedicated workers'? Contradictions of domesticity in the 'mission of sisterhood,' Travancore, South India," in Maternities and Modernities. Colonial and Postcolonial Experiences in Asia and the Pacific, ed. Kalpana Ram and Margaret Jolly, Cambridge: Cambridge University Press, 1998, pp. 81-113.

74 Haggis, “'Good wives and mothers' or 'dedicated workers'?” p. 93.

75 Kent, Converting Women, p. 5.

76 Ibid., p. 6. 
My material suggests that such distinctions are blurred, perhaps even unnecessary in the first place. Development agendas are very much a matter of bringing "far-reaching changes to people's daily lives and everyday practices." Yet the young women speak an existential language that is very close to that of religious conversion. They testify to a sharp break in their lives, one whereby their former self appears constrained, oppressed, bound by social restrictions; while the new self delights in an expansive opening to the world. If the religious phenomenologists such as Heidegger and James were indeed describing an interiority that remains entirely locked inside the subject, such close parallels would not be possible. But the gulf between the two versions may not be so vast as it appears, as long as we recall that religious conversion, however "private" it may seem to the outsider, is in experience the opening up of a new and intense relationship between self and divine Other, and not an event locked within the isolated subjectivity of the Cartesian cogito. Whether the newfound and expansive sense of agency stems from an oppressed group's experience of a profoundly social transformation of daily existence, or from a new relationship with God, both allow the subject to re-experience the "givenness" of social life as something that can be changed and altered.

\section{Acknowledgements}

This is to thank Margaret Jolly and Hyaeweol Choi for organising a stimulating conference that provided the occasion for reflecting on a theme I have long intended to go deeper into, namely the relationship between Christianity, development and activism in South India. 
This text taken from Divine Domesticities: Christian paradoxes in Asia and the Pacific, edited by Hyaeweol Choi and Margaret Jolly, published 2014 by ANU Press, The Australian National University, Canberra, Australia. 